\title{
The influence of vocal rehabilitation methods on communication in patients with total laryngectomy
}

\author{
Beáta Kiss', Boris Casautanu'2 , Adriana Neagos ${ }^{1}[$ \\ "George Emil Palade" University of Medicine, Pharmacy, Science and Technology, Targu Mures, Romania \\ ${ }^{2}$ County Emergency Clinical Hospital of Targu Mures, Targu Mures, Romania
}

\section{ABSTRACT}

BACKGROUND. Considering the problematic social integration after total laryngectomy, evaluation of communicational aptitudes of patients after the surgical intervention is necessary in order to optimize their vocal rehabilitation process.

MATERIAL AND METHODS. A prospective clinical study was conducted on 24 randomly selected patients of the Otolaryngology Clinic of Targu Mures County Emergency Clinical Hospital that underwent total laryngectomy. We adapted and implemented the questionnaire for Self-Evaluation of Communication Experiences after Laryngectomy - SECEL. Three groups of patients were created: the first containing those with voice prosthesis, the second those using electrolarynx and esophageal voice, and the third with no rehabilitation. We used the Kruskal-Wallis test for the statistical analysis of the results.

RESULTS. The mean age of the patients included in our study group was 63 years (+/- $7.56 \mathrm{SD}) .95 .83 \%$ of the participants were male. $79.16 \%$ were married. The majority $(87.50 \%)$ of patients were retired. In $75 \%$ of cases, 0 to 5 years have passed since the surgery. $75 \%$ reported diminished communication after surgery. The test used to determine if significant differences were present between the examined groups showed a p-value of 0.1329 (total scores), p-value of 0.3244 (the first score of SECEL), p-value $=0.6004$ (the second score of SECEL) and a p-value of 0.0613 (the third score of SECEL). Given that p was higher than 0.05 , the null hypotheses could not be rejected. The patients who underwent rehabilitation by tracheoesophageal prosthesis showed the best results in all tested categories.

CONCLUSION. The SECEL questionnaire adapted in Romanian language could be used as a valid screening instrument in order to improve voice rehabilitation, but it needs further testing.

KEYWORDS: total laryngectomy, communication, voice rehabilitation, voice prosthesis, questionnaire.

\section{INTRODUCTION}

The social integration following total laryngectomy is problematic for patients, who frequently report feelings of depression, anxiety and selfisolation. The surgical intervention is a mutilating one, the tracheal stoma provoking prejudice and social stigma. At the same time, basic functions such as interpersonal communication or intimate relationships suffer alterations. Patients often become incapable to maintain a position in the workforce, this resulting in a decrease in income and standard of living ${ }^{1}$. Patients who undergo total laryngectomy report psychosocial and func- tional strain, such as altered swallowing, communicational difficulties, cervical muscle weakness and lowered energy levels. The psychosocial manifestations are represented by depression and feelings of regret ${ }^{2}$.

Taking into consideration the major negative effects over the private life and social integration of these patients, it is highly important to evaluate not only the survival rates and tumor eradication but the quality of life as well ${ }^{3}$.

A study aimed at unveiling the effect of laryngectomy on the quality of communication and postoperative quality of life demonstrated that, regardless of the communication method used, the surgical 
intervention had an overall negative impact on the postoperative communication and the quality of life. The factors linked to the quality of voice and the aesthetics of the different communication methods used influenced the auto-evaluation of the quality of life in these patients. These were found to be more important than other persons' capacity to understand them ${ }^{4}$.

Although no consensus exists regarding the notion of quality of life, three fundamental aspects define it, such as: subjectivity, multidimensionality and the presence of positive and negative dimensions. Their development gave birth to the definition of quality of life being, according to the World Health Organization, "an individual's perception of their position in life in the context of the culture and value systems in which they live, and in relation to their goals, expectations, standards and concerns" 5 .

The loss of the ability to communicate orally has an increased potential for conflict, presenting a major negative impact over the patients' communication in private settings or professional life. The vocal rehabilitation aims to establish a new way of communication $^{6}$.

From the currently existing vocal rehabilitation methods, at present, the tracheoesophageal prosthesis is considered as the "gold standard". This was first introduced in medical practice by Blom and Singer in 1979. The procedure consisted in the creation of a shunt between the trachea and the oesophagus with the insertion of a medical grade silicone prosthesis in the puncture wound, equipped with a unidirectional valve that permitted the passage of expired air from the lungs into the oesophagus, but at the same time, prevented the oesophageal secretions to enter the lower respiratory tract. In the last decades, these devices' functionality and safety was proven ${ }^{7}$.

\section{MATERIAL AND METHODS}

We conducted a prospective study on 24 randomly selected participants, starting from July 2019 until the present day. Patients included were in evidence at the Otolaryngology Clinic of The County Emergency Clinical Hospital of Targu Mures, with malignant laryngeal tumors for which total laryngectomy was performed. Participation in the study was proposed to all the patients presenting to the clinic that fit the inclusion criteria, namely: laryngeal malignancy for which a total laryngectomy was performed, with or without vocal rehabilitation. Exclusion criteria were: laryngeal malignancy without surgical treatment, the presence of other malignant tumors and refusal to participate in the study. All participants provided a written consent and completed the SECEL questionnaire adapted in Romanian language (Figure 1).

For the present study, a questionnaire for selfevaluation of communication experiences in laryngectomized patients of international circulation was used. The translation of the document was performed individually by two otolaryngology specialists, both speaking Romanian and English language at an advanced level. The results were correlated and the final document was prepared.

The questionnaire uses a Likert-scale for patient's self-evaluation of communication. The first part contains questions pertaining to socio-demographic data, including sex, age, the primary method of communication (voice prosthesis, oesophageal voice, electrolarynx or other - including the lack of rehabilitation and the whispered speech), provenance (urban, rural), the year of surgery, education level, current occupation, profession and marital status.

The next 34 questions are grouped into three categories. The first one is represented by the general category, containing questions $1-5$, which refers to the patient's general attitude towards his/ her state of calm and relaxation and acknowledgement of the illness and surgical treatment. The second category, that of the environment, contains 14 questions and it pertains to the patient's use of verbal communication skills in different environments. The third category, representing the attitude, consists of the last 15 questions, and describes the patient's attitude towards the way he/ she communicates, self-perception and the way others perceive him/her.

Each question is evaluated on a 4-step scale, from 0 (Never) to 3 (Always). The answers must be provided considering the communication experiences of the last 30 days. The scores for each category are calculated using simple summing. The score is the following: the first category 0-15 points, the second category $0-42$ points, the third category $0-45$ points. The total sum is 102 points. The higher the score is, the greater level of communicational dysfunction is perceived by the patient.

The last question refers to the sum of communication and it has three possible answers (more, less, the same amount). This question is not included in the grading system.

We analysed and processed the data from the SECEL questionnaire using Microsoft Excel, creating a database. The socio-demographic data were analysed by sex, age, provenance, education level, current occupation, profession, marital status. The 
Chestionarul SECEL de evaluare a calitătii comunicìrii la pacientii cu laringectomie totală adaptat în limba romainầ

Prin completarea acestui chestionar îmi declar acordul ca datele mele personale consemnate in fiseie de

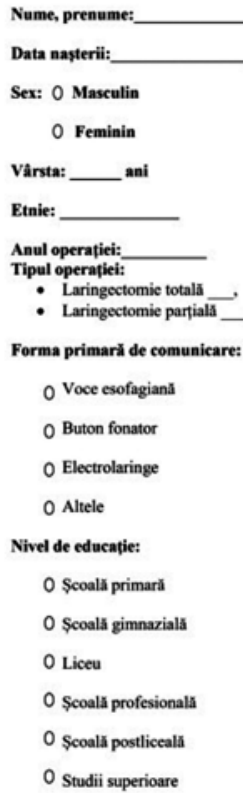

Ocupatia: Fără ocupatic _, Salariat _, Lucrător pe cont propriu _, Pensionar _. Somer

Cu ce vĭ ocupatî/ cu ce v-ati ocupat?

Status marital: 0 Singur

$$
\begin{aligned}
& \text { O Cassatorit } \\
& \text { O Divortat } \\
& \text { O Despartit } \\
& \text { O Vaduv }
\end{aligned}
$$

Mai jos găsitit 35 de intrebări referitoare la comunicarea dupa laringectomic. Aceste experiente au fost raportate de caltre pacienti laringectomizati. Cititi fiecare intrebare dumneavoastrẩ de acum saul care descrie opinia dumneavoastrá referitoare la starea

\begin{tabular}{|c|c|c|c|c|c|}
\hline Nr. & & Mereu & Des & Uneori & Niciodată \\
\hline 1. & $\begin{array}{l}\text { Suntefi relaxat si confortabil } \\
\text { cand comunicati cu alte } \\
\text { persoane? }\end{array}$ & 3 & 2 & 1 & 0 \\
\hline 2. & $\begin{array}{l}\text { V-ati descrie ca o persoaná } \\
\text { calma? }\end{array}$ & 3 & 2 & 1 & 0 \\
\hline 3. & $\begin{array}{l}\text { Sunteti o persoanal activă, } \\
\text { sociabila, vorbáreata?? }\end{array}$ & 3 & 2 & 1 & 0 \\
\hline 4. & $\begin{array}{l}\text { Recunoasteti in fata persoanei } \\
\text { cu care vorbiti cal ati avut } \\
\text { laringectomie? }\end{array}$ & 3 & 2 & 1 & 0 \\
\hline
\end{tabular}
experientele din anul trecut sau la cele cu mai multi ani in urmâ. Exemplul de mai jos vã arată cum să procedati:

\begin{tabular}{|c|c|c|c|c|c|}
\hline 5. & 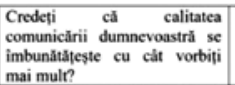 & 3 & 2 & 1 & 0 \\
\hline 6. & $\begin{array}{l}\text { Freceventati localuri mai rar din } \\
\text { cauza felului in care } \\
\text { comunicati? }\end{array}$ & 3 & 2 & 1 & 0 \\
\hline 7. & $\begin{array}{l}\text { Vi se pare dificil să atrageti } \\
\text { atentia oamenilor cánd vorbifi? }\end{array}$ & 3 & 2 & 1 & 0 \\
\hline 8. & $\begin{array}{l}\text { Vi se pare dificil să strigati sau } \\
\text { să atrageti atentia oamenilor? }\end{array}$ & 3 & 2 & 1 & 0 \\
\hline 9. & $\begin{array}{l}\text { Aveti impresia, câ oamenii nu } \\
\text { val pot intelege? }\end{array}$ & 3 & 2 & 1 & 0 \\
\hline 10. & $\begin{array}{l}\text { Aveti impresia ch trebuie sa } \\
\text { repetati de cateva ori ceea ce } \\
\text { spuneti in cursul unei } \\
\text { conversatii ca sa fiti inteles? }\end{array}$ & 3 & 2 & 1 & 0 \\
\hline
\end{tabular}

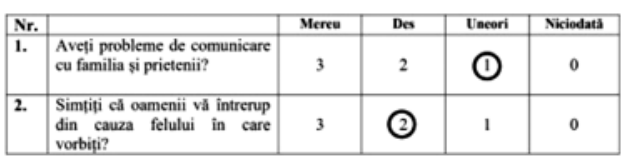

2

\begin{tabular}{|c|c|c|c|c|c|}
\hline Nr. & & Mereu & Des & Uneori & Niciodată \\
\hline 18. & $\begin{array}{l}\text { Intaimpinati dificultâti in sitatiii } \\
\text { sociale sau când participati la } \\
\text { săbatori sau petreceri? }\end{array}$ & 3 & 2 & 1 & 0 \\
\hline 19. & $\begin{array}{l}\text { Folositi telefonul mai rar decát } \\
\text { v-ati dori? }\end{array}$ & 3 & 2 & 1 & 0 \\
\hline 20. & $\begin{array}{l}\text { Va simtiti marginalizat caind } \\
\text { suntefi intr-un grup de oamnei? }\end{array}$ & 3 & 2 & 1 & 0 \\
\hline 21. & $\begin{array}{l}\text { Vã limitati viała sociala sau } \\
\text { cea personala? }\end{array}$ & 3 & 2 & 1 & 0 \\
\hline
\end{tabular}

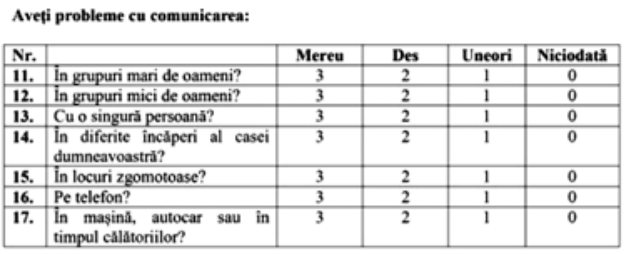

\begin{tabular}{|c|c|c|c|c|c|}
\hline Nr. & & Mereu & Des & Uneori & Niciodată \\
\hline 22. & Depresiv & 3 & 2 & 1 & 0 \\
\hline 23. & $\begin{array}{l}\text { Frustrat caind vorbiti cu familia } \\
\text { sau prietenii și ei nu vă } \\
\text { inteleg? }\end{array}$ & 3 & 2 & 1 & 0 \\
\hline 24. & Diferit sau ciudar? & 3 & 2 & 1 & 0 \\
\hline 25. & $\begin{array}{l}\text { Exitati sa faceti cunostiintal cu } \\
\text { oameni noi din cauza } \\
\text { comunicalrii dumneavoastra? }\end{array}$ & 3 & 2 & 1 & 0 \\
\hline 26. & Suntefi exclusi din conversatii? & 3 & 2 & 1 & 0 \\
\hline 27. & $\begin{array}{l}\text { Evitati sa vorbiti cu oamenii } \\
\text { din cauza felului in care } \\
\text { comunicati? }\end{array}$ & 3 & 2 & 1 & 0 \\
\hline 28. & $\begin{array}{l}\text { Simtiti cá oamenii incearcá sa } \\
\text { vă termine propozitiile sau sa } \\
\text { vâ ghiceascá cuvintele? }\end{array}$ & 3 & 2 & 1 & 0 \\
\hline 29. & $\begin{array}{l}\text { Simtiti cal oamenii val intrenup } \\
\text { când vorbiti? }\end{array}$ & 3 & 2 & 1 & 0 \\
\hline 30. & $\begin{array}{l}\text { Oamenii vă spun că nu vă pot } \\
\text { intclege? }\end{array}$ & 3 & 2 & 1 & 0 \\
\hline 31. & $\begin{array}{l}\text { Simtiti ca oamenii se supara } \\
\text { din cauza modului in care } \\
\text { comunicati? }\end{array}$ & 3 & 2 & 1 & 0 \\
\hline 32. & $\begin{array}{l}\text { Simtiti cá oamenii vá evita din } \\
\text { cauza modului in care } \\
\text { comunicati? }\end{array}$ & 3 & 2 & 1 & 0 \\
\hline 33. & $\begin{array}{l}\text { Simtiti ca oamenii vorbese cu } \\
\text { dumneavoastra intr-un mod } \\
\text { diferit din cauza felului in care } \\
\text { comunicati? }\end{array}$ & 3 & 2 & 1 & 0 \\
\hline 34. & $\begin{array}{l}\text { Simtiti ca familia si prictenii } \\
\text { nu infeleg cum este s } \\
\text { comunice o persoana cum } \\
\text { comunicati dumneavoastra? }\end{array}$ & 3 & 2 & 1 & 0 \\
\hline
\end{tabular}

Vi se pare cŭ din cauza comunicării dumneavoastră:

Puteți afirma că đin cauza comunicării dumneavoastră vă simtiti:

\begin{tabular}{|l|l|c|c|c|}
\hline 35. & $\begin{array}{l}\text { Vorbiti la fel de mult acum ca } \\
\text { si inainte de operatic? }\end{array}$ & Da & Mai mult & Mai putin \\
\hline
\end{tabular}

Data.

Semnitura,

Figure 1. SECEL Questionnaire in Romanian language. 
answers to the last independent question (question nr. 35) were examined as well. The scores for categories I-III, as well as the total score were calculated for each patient. A database was created containing the results of the questionnaires.

In the end, we created three groups, comparing the results obtained by those with voice prosthesis to the results of patients without voice rehabilitation and to those communicating using electrolarynx or esophageal voice. The group containing those with tracheoesophageal voice prosthesis consisted of 7 patients. The second group, including those rehabilitated by electrolarynx or esophageal voice, consisted of 8 patients. The third group, that of patients with no rehabilitation, included 9 participants.

The database, figures and tables were created using Microsoft Excel. For the statistical analysis of the data a non-parametric test, the ANOVA Kruskal-Wallis test, was used, which was performed with the help of the following site: https://www.socscistatistics.com.

\section{RESULTS}

Since July 2019, 24 patients gave express consent to participate in the present ongoing study. Written consent was obtained from all participants. Mean age was 63 years (+/- 7.56 SD - minimum 49, maximum 79). 23 patients, out of the 24 included in the study, were male $(95.83 \%)$. From the data regarding marital status, we identified $79.16 \%$ of patients as married, $12.5 \%$ were widowed, $8.33 \%$ reported to be single. The majority of patients $(87.5 \%)$ were retired, $4.16 \%$ were unemployed, $8.33 \%$ were employed. Another important detail was the level of education. In Figure 2, one can see that most of the patients included in the study reported to have completed primary school or a professional school (37.5\%). A higher form of education was reported only by 2 patients $(8.33 \%)$.

In $75 \%$ of cases, $0-5$ years have passed since the operation, in $8.33 \%$ 5-10 years, in $12.50 \% 10-15$ years, in $4.16 \% 15$-20 years.

All 24 patients included in the study were divided into three groups according to their primary communication method after total laryngectomy (Figure 3): 7 patients used a tracheoesophageal voice prosthesis $(29.16 \%), 8$ patients were rehabilitated with electrolarynx (2 patients, $8.33 \%$ ) or esophageal voice (6 patients, $25 \%$ ), 9 patients received no voice rehabilitation method $(37.5 \%)$.

The patients filled in the SECEL Questionnaire in Romanian language. As shown in Figure 4, the total scores for the three groups were as follows:

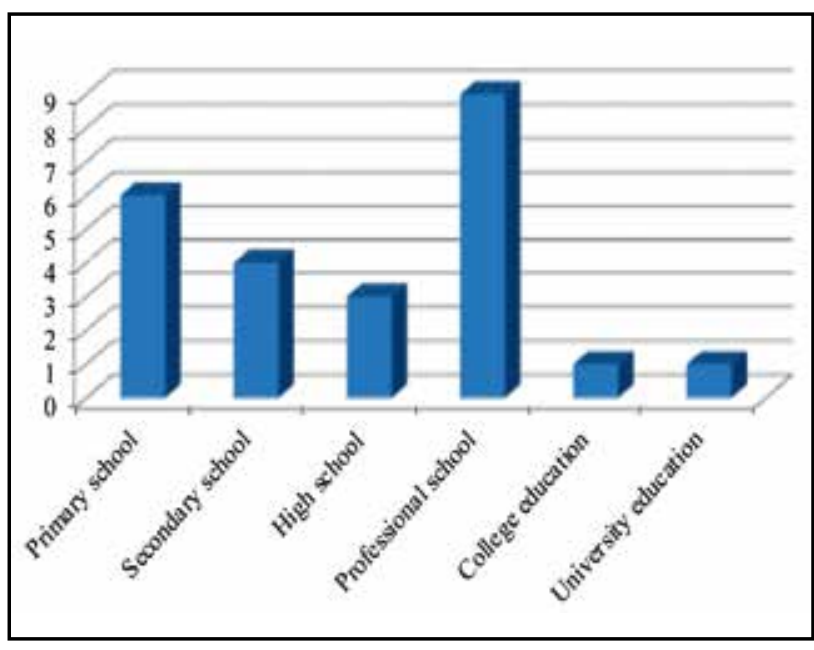

Figure 2. Level of education of the patients included in our study group.

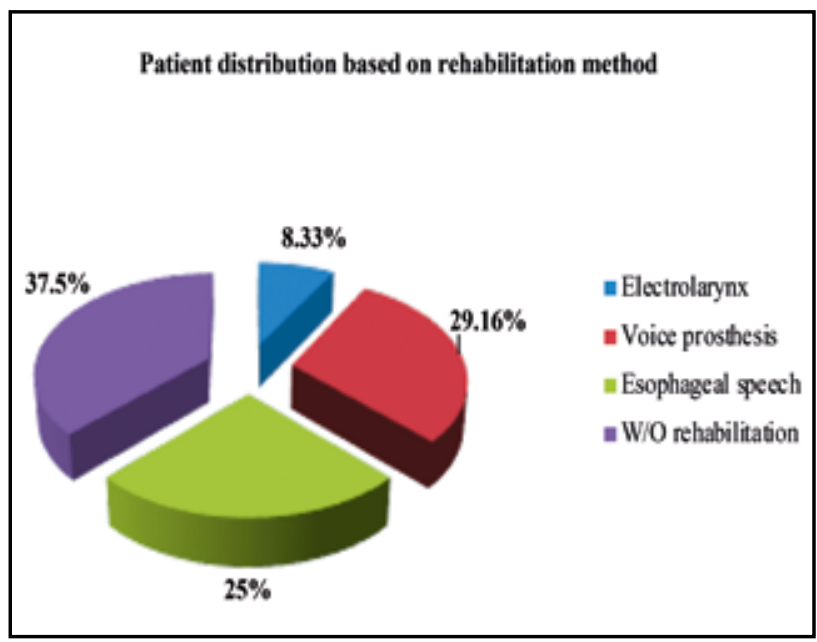

Figure 3. Patients' distribution based on the primary method of communication after total laryngectomy.

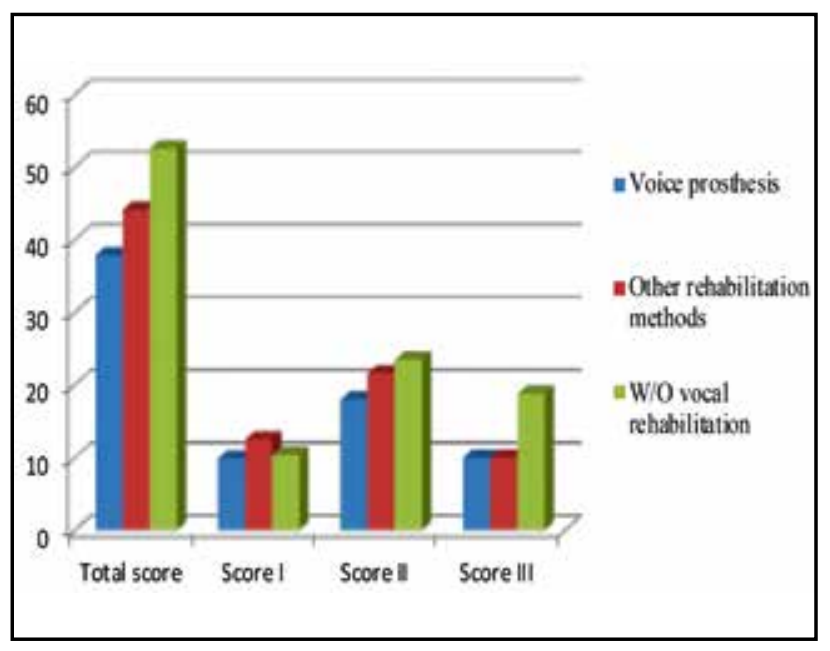

Figure 4. The obtained score for each category of questions, according to the examined groups. 
Table 1. The results of the ANOVA Kruskal-Wallis test.

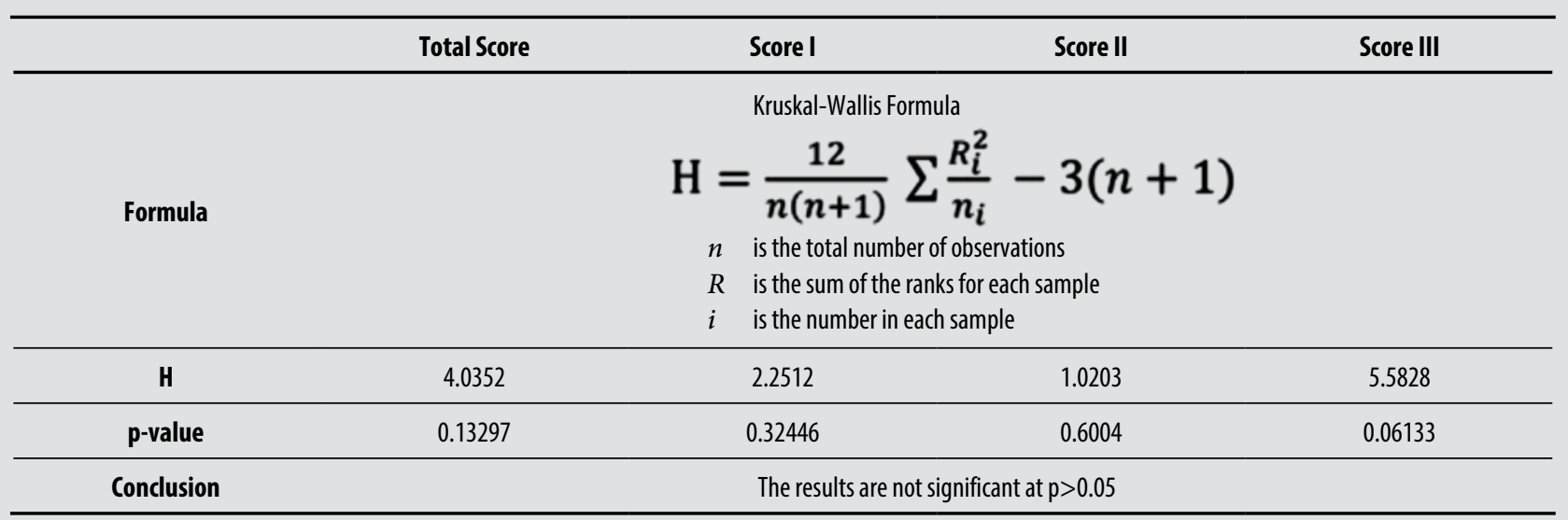

those with voice prosthesis scored a total of 265 points, the mean score per patient being 37.85 ; the second group, including those with electrolarynx and esophageal voice, scored a total of 353 points, the mean score per patient being 44.12; the third group, including patients who did not benefit from vocal rehabilitation, scored a total of 473 points, the mean being 52.55 .

In case of the first category of questions, those with voice prosthesis scored 69 points (mean score of 9.85), those with other types of vocal rehabilitation scored 116 points (mean score of 12.5), those with no rehabilitation scored 93 points (mean score of 10.33).

The second category had the following results: those with voice prosthesis scored 126 points in total (mean score of 18 ), the patients with other rehabilitation methods scored 173 points in total (mean score of 21.62), those not rehabilitated scored 211 points in total (mean score of 23.44).

In the third category of questions, the first group scored 70 points total, with a mean of 10 points per patient, the second group scored 80 points, with a mean of 10 points per patient, while the third group scored a total of 169 points, with a mean score of 18.77 .

The Kruskal-Wallis test was employed at alpha value 0.05 . The $p$-value resulted from the calculation for the SECEL Questionnaire total score was 0.1329 . The null hypothesis could not be rejected. Considering that $p$-value was higher than 0.05 , there was no statistically significant difference between the mean ranks of any pair (Table 1 ).

The first category was examined using the same test. $P$-value was 0.3244 . The null hypothesis was retained. The difference between the mean ranks was not big enough to be statistically different. The examination of the second category resulted in a $p$-value of 0.6004 . At $p<0.05$, the null hypotheses could not be rejected. The third category showed a $p$-value of 0.0613 . The difference between the mean ranks was not big enough to be statistically different.

The independent question (question nr. 35) revealed that $75 \%$ of patients considered to be communicating less after the surgical intervention, $8.33 \%$ reported an increase in communication, $16.66 \%$ did not observe any alteration.

\section{DISCUSSIONS}

According to the results, most patients included in the study were male $(95.83 \%)$, mean age was 63 years $(+/-7.56 \mathrm{SD})$, and $75 \%$ of patients underwent total laryngectomy in the past 5 years. The preponderance of male patients, the age and time passed since the surgical intervention were consistent with anterior studies ${ }^{8-10}$. The short timespan from the surgery could be attributed to the increased frequency of postoperative check-ups. At the same time, the need for guidance in order to attain optimal voice rehabilitation is the most important in this period.

The significance of the first postoperative year is underlined by several studies. One of them performed by Scott et al. on 47 patients, analysing the quality of life (QoL) after total laryngectomy, showed that all aspects of quality of life are reduced after the surgical intervention. The decrease in the QoL stabilizes in time; this stabilization process takes place in all cases, regardless of the socioeconomic status 8,11 . Social and emotional support of patients with lower socio-economic status showed a positive influence over their perceived quality of life and voice. These results were cor- 
roborated with the only study correlating quality of life with socio-economic status, the conclusion showing similarity between the two studies ${ }^{12}$.

The results show that $79.16 \%$ of patients are married, this having a possible positive effect over the auto-perception of patients through the emotional support it offers, even in the case of those with no voice rehabilitation.

Our results show that 15 out of 24 patients finished high school, this number representing $62.5 \%$ of the total. Only two patients had higher education. These results are consistent with the results of the study which analyses the QoL postlaryngectomy, where $46.8 \%$ reported finishing compulsory education. In this study including 47 patients, 10 reported higher education, twice as much as in our study ${ }^{8}$. The most frequently reported education level was professional school in our patient lot $(37.5 \%)$.

Only $8.33 \%$ of patients were employed, $87.5 \%$ living on pension. This highlights the importance of cancer prevention programs, as well as that of an efficient postoperative rehabilitation, including psychotherapy and phoniatrics, of which we do not dispose at this time. These patients end up representing an economic burden for society.

According to a study from Germany, participants of rehabilitation programs had four times higher chance of developing verbal speech than those who did not partake in such programs. From the 309 participants included in their study, only $14 \%$ did not receive rehabilitation until the end of the first postoperative year. In the first six months, approximately $47 \%$ of patients used one of the alternative communication methods - voice prosthesis, electrolarynx or esophageal speech ${ }^{13}$. Comparatively with these results, in our study almost $40 \%$ of patients were without postoperative rehabilitation.

Considering that the higher the score, the greater the perceived communicational dysfunction, our results show that the lowest total score was obtained by those using voice prosthesis. The lowest score in the first, second and third category was also seen in those using the tracheoesophageal prosthesis. In the second and third categories of questions, the highest scores obtained the group without rehabilitation. This group also had the highest overall score. There were no statistically significant differences between the mean ranks. A larger sample size might help us obtain better results in the future.

The statistical analysis for the total score of the predetermined groups, as well as the individual scores for each category, was conducted using the Kruskal-Wallis test. This was used to compare the three independent samples, in order to determine whether the samples originated from the same distribution. The results were not statistically significant. A possible cause for this could be the small sample size.

The study shows better results in case of rehabilitated patients compared to those with no rehabilitation in all categories. The largest discrepancy can be seen in the third category, reflective of the patient's attitude towards his/her communication method, self-perception and the way others perceive them.

Patients rehabilitated by tracheoesophageal prosthesis presented better results in all categories examined compared to those with other methods of rehabilitation or those without rehabilitation.

Participants with no rehabilitation unanimously reported a decrease in communication after the surgery. Four patients of those with a restored voice declared to communicate just as much, and only one participant responded with "More" to the last question.

A possible formulation error was identified by participants in the case of the question concerning the primary method of communication, where the option "without voice" was not available. The same weakness was pointed out in the Portuguese version of the questionnaire. According to the authors, a possible explanation for the lack of this option is the increased frequency of post-operative vocal rehabilitation utilized in the country of origin, the United States of America ${ }^{14}$.

\section{CONCLUSIONS}

The management of malignant laryngeal tumors require correct diagnosis, adequate staging and the selection of the best treatment method, as well as rigorous postoperative observation. Post-laryngectomy social integration is problematic for patients, who frequently report feelings of depression, anxiety and self-isolation. The low rate of work enrolment underlines the importance of cancer prevention programs, as well as efficient postoperative rehabilitation, including psychotherapy and phoniatric services, which at present are missing from our arsenal. Considering the major negative effects over the private life and social integration of these patients, we find it imperative to evaluate the quality of their communication in order to provide the best chance for an optimal rehabilitation. The present study serves as an indicator of the importance of vocal rehabilitation, the results showing higher rates of satisfaction in those who regained their ability to communicate verbally.

The SECEL questionnaire adapted in Romanian 
language could be utilized as a routine screening instrument to help identify patients with higher risks of developing psychosocial difficulties; however, it needs further testing in order to underline possible errors and shortcomings.

Conflict of interest: All authors declare that there are no conflicts of interest in this work.

Contribution of authors: All authors have contributed equally to this work.

Financial discloser: None.

\section{REFRENCES}

1. Perry A, Casey E, Cotton S. Quality of life after total laryngectomy: functioning, psychological well-being and self-efficacy. Int J Lang Commun Disord. 2015;50(4):467-75. DOI: 10.1111/14606984.12148 .

2. Noonan BJ, Hegarty J. The impact of total laryngectomy: the patient's perspective, Oncol Nurs Forum. 2010;37(3):293-301. DOI: 10.1188/10.ONF.293-301.

3. Roick J, Keszte J, Danker H, Meister EF, Vogel HJ, Jenzewski EM, et al. Social integration and its relevance for quality of life after laryngectomy. Laryngorhinootologie. 2014;93(5):321-6. DOI: 10.1055/s-0033-1358715.

4. Sharpe G, Camoes Costa V, Doube W, Sita J, McCarthy C, Carding P. Communication changes with laryngectomy and impact on quality of life: a review. Qual Life Res. 2019;28(4):863-77. DOI: 10.1007/s11136-0182033-y.

5. Fleck MP, Chachamovich E, Trentini C. Development and validation of the Portuguese version of the WHOQOL-OLD module. Rev Saude Publica. 2006;40(5):785-91. DOI: 10.1590/S003489102006000600007.

6. Fotescu Zamfir M, Cristescu E, Ghiuzan L, Magureanu M, Stanescu
C, Costache AN, et al. Behind the silence there is a new voice. [Internet]. ORL.ro. 2017;34(1):20-4. DOI: 10.26416/ Orl.34.1.2017.463. Available from: https://www.medichub.ro/reviste/orl-ro/in-spatele-tacerii-exista-o-noua-voce-id-463-cmsid-63.

7. Hilgers FJM, van den Brekel MWM. Vocal and speech rehabilitation after laryngectomy. In: Flint PW, Haughey BH, Lund VJ, Niparko JK, Robbins KT, Thomas JR, et al. Cummings Otolaryngology - Head and Neck Surgery. 6th edition. Vol 1. Elsevier Saunders; 2015, p.1732-50.

8. Scott AJ, McGuire JK, Manning K, Leach L, Fagan JJ. Quality of life after total laryngectomy: evaluating the effect of socioeconomic status. J Laryngol Otol. 2019;133(2):129-34. DOI: 10.1017/ S0022215119000215.

9. da Silva AP, Feliciano T, Vaz Freitas S, Esteves S, Almeida E, Sousa C. Quality of life in head and neck cancer submitted to total laryngectomy. J Voice. 2015;29(3):382-8. DOI: $10.1016 / \mathrm{j}$. jvoice.2014.09.002.

10. Neagos A, Olteanu C, Manuc D, Bitere OR, Cobzeanu MD, Hinganu MV, et al. Quality of life and social impact in patients with laryngeal tumors after radiotherapy. Revista de Cercetare si Interventie Sociala. 2020;71:149-61. DOI: 10.3378/rcis.71.10.

11. Singer S, Danker H, Guntinas-Lichius O, Oeken J, Pabst F, Schock $\mathrm{J}$, et al. Quality of life before and after total laryngectomy: results of a multicenter prospective cohort study. Head Neck. 2014;36(3):359-68. DOI: 10.1002/hed.23305.

12. Agarwal SK, Gogia S, Agarwal A, Agarwal R, Mathur AS. Assessment of voice related quality of life and its correlation with socioeconomic status after total laryngectomy. Ann Palliat Med. 2015;4(4):169-75. DOI: 10.3978/j.issn.2224-5820.2015.09.05.

13. Singer S, Vogel HJ, Guntinas-Lichius O, Erdmann-Reusch B, Fuchs $\mathrm{M}$, Taylor K, et al. Multicenter prospective study on the use and outcome of rehabilitation after total laryngectomy in Germany. Head Neck. 2019 ;41 (4):1070-9. DOI: 10.1002/hed.25540.

14. Fahl GB, Goulart BNG. Transcultural adaptation of the Sef-Evaluation of Communication Experience After Laryngectomy (SECEL) instrument into Brazilian Portuguese, Audiol Commun Res. 2016;21:e1678. DOI: 10.1590/2317-6431-2016-1678.

This is an open access article published under the terms and conditions of the Creative Commons Attribution-NonCommercial-NoDerivatives 4.0 International (CC BY-NC-ND 4.0) License (https://creativecommons.org/licenses/by-nc-nd/4.0/). CC BY-NC-ND 4.0 license requires that reusers give credit to the creator by citing or quoting the original work. It allows reusers to copy, share, read, download, print, redistribute the material in any medium or format, or to link to the full texts of the articles, for non-commercial purposes only. If others remix, adapt, or build upon the material, they may not distribute the modified material. 